\title{
Low band-gap polymers incorporating benzotriazole and 5,6-dialkoxy-benzothiadiazole as solution processable electrochromic materials
}

\author{
W. T. Neo ${ }^{1}, Q . \mathrm{Ye}^{1}, \mathrm{X} . \mathrm{Wang}^{1}, H . \mathrm{Yan}^{1}, J . X u^{1,2^{*}}$ \\ ${ }^{1}$ Institute of Materials Research and Engineering, 3 Research Link, Agency for Science, Technology and Research \\ (A*STAR), 117602 Singapore, Singapore \\ ${ }^{2}$ Department of Chemistry, National University of Singapore, 3 Science Drive 3, 117543 Singapore, Singapore
}

Received 10 October 2014; accepted in revised form 21 December 2014

\begin{abstract}
Two series of donor-acceptor type conjugated polymers bearing benzotriazole or 5,6-dialkoxy-benzothiadiazole as acceptors unit are synthesized via Stille coupling. The optical, electrochemical, spectroelectrochemical characterizations and theoretical calculations are carried out. The polymers display excellent solubility in common organic solvents upon the introduction of long aliphatic side chains. The electrochromic performances of the polymers are also studied. Upon oxidation, the polymers switch from magenta or blue to a transmissive light blue state. In particular, respectable optical contrasts of about 44 and $40 \%$ are obtained in the visible and near infrared (NIR) region respectively for P2. The polymers also reveal fast switching of about from one second to a few seconds. In addition, P2 exhibits a high coloration efficiency of 518 and $561 \mathrm{~cm}^{2} / \mathrm{C}$ in the visible and NIR region respectively. The promising electrochromic behaviour of these polymers, together with the enhanced solubility will allow large-scale processing and advancement towards real applications.
\end{abstract}

Keywords: polymer synthesis, molecular engineering, donor-acceptor, electrochromic, solution processable

\section{Introduction}

Electrochromic materials that display color changes upon an applied external bias have received widespread attention as they have been heralded as the next-generation color-changing technology. In this regard, conjugated polymers are one type of the most promising candidates as electrochromic materials. Researchers have ingeniously utilized the distinct advantage of conjugated polymers - ease of structural modifications, for color-tuning through bandgap manipulations [1]. One particular strategy that has been widely employed for the adjustment of frontier orbital energy levels is the donor-acceptor (D-A) approach [2]. Benzothiadiazole (BT) and related derivatives [3] have been intensively investigated as the acceptor moiety in donor-acceptor type conjugated polymers [4-11]. To tune the physical properties of the functional polymer, e.g., varying the frontier orbital energy level and absorption behaviour, a large number of electron-withdrawing building blocks have been synthesized based on the similar chemical structure of benzothiadiazole. Prevailing chemical strategies to modify the electronic property of BT unit include a) replacement of the $\mathrm{S}$ atoms to $\mathrm{O}$ [12-15], -NR [10, 16], - $\mathrm{CR}_{2}[17,18]$, Se [19, 20], $\mathrm{Te}[20]$; b) replacement of the $\mathrm{C}-\mathrm{H}$ part with $\mathrm{N}$ [2123], $\mathrm{C}-\mathrm{F}$ [24-26], $\mathrm{C}-\mathrm{NO}_{2}$ [27], $\mathrm{C}-\mathrm{OR}[28,29]$ and c) extension of the $\pi$-conjugation [30-37]. Out of all the building blocks available in the literatures, those with flexible chains for enhanced solubility of corre-

\footnotetext{
${ }^{*}$ Corresponding author, e-mail: jw-xu@imre.a-star.edu.sg

(c) BME-PT
} 
sponding polymers are typically employed for the preparation of solution processable D-A conjugated polymers [38].

As an on-going research progress on design and synthesis of EC materials [39-42], we are keen to incorporate BT based acceptor moieties into D-A polymers to prepare high performance solution processable EC polymers. In this regard, the acceptor building block needs suitable electron affinity for frontier orbital energy level control and functional sites for the attachment of solubilizing chains. Benzotriazole and 5,6-dialkoxy benzothiadiazole (Figure 1) are the target building blocks that contain both features. First of all, the highest-occupied molecular orbital (HOMO) energy level of the final electrochromic polymer is of great importance to control the oxidation of the polymer in the EC device, which thus controls the saturation working voltage of the device [1]. To lower the energy consumption and to enhance the lifetime of EC device, a lower working voltage is desired and hence a higher HOMO is more desirable. For these two building blocks, their electron affinity is lowered compared with that of BT, due to the replacement of the sulfur with $-\mathrm{NR}$ and addition of two electron donating alkoxyl groups. Secondly, both of the two building blocks have functional sites which allow facile attachment of solubilizing chains. Furthermore, both building blocks can be conveniently prepared in large quantities following established chemical synthesis, which allows large scale synthesis of the final polymers. Owing to these advantages, implementation of these two BT derived building blocks into D-A type conjugated polymer would be a very promising approach to prepare high performance solution processable electrochromic materials.
Herein, we report the synthesis of two series of benzotriazole or 5,6-dialkoxyl-benzothiadiazole-containing D-A type conjugated polymers via Stille cross coupling reactions. With the incorporation of long aliphatic side chains on the moieties, all the polymers P1-P5 (Figure 1) exhibit good solubility, rendering solution processing techniques applicable. Their physical properties are well characterized, both experimentally and theoretically. The utilization of these materials as electrochromes in electrochromic devices is investigated. The polymers are found to be magenta or blue in their neutral states and partially transmissive in the fully oxidized states. The electrochromic properties of the polymers are promising, such as fast switching, respectable optical contrasts, coloration efficiencies and stabilities under ambient conditions.

\section{Experimental section}

\subsection{Materials}

All materials were purchased from Aldrich and used as received unless otherwise stated. Tetrahydrofuran (THF) and toluene were distilled over sodium/benzophenone. Triethylamine (TEA) was purified by refluxing with calcium hydride and then distilled. Dimethylformamide (DMF, 99\%) from Tedia Company Inc. was dried with molecular sieves (4 $\AA$ ) and used directly without filtration or distillation. Indium tin oxide (ITO, $60 \Omega / \mathrm{sq}$ ) coated poly(ethylene terephthalate) (PET) was obtained from Aldrich and used as the substrate.

\subsection{Instrumentation}

${ }^{1} \mathrm{H}-\mathrm{NMR}(400 \mathrm{MHz})$ and ${ }^{13} \mathrm{C}-\mathrm{NMR}(100 \mathrm{MHz})$ were obtained in $\mathrm{CDCl}_{3}$ with Tetramethylsilane (TMS) as the internal reference on Bruker spectrometers.
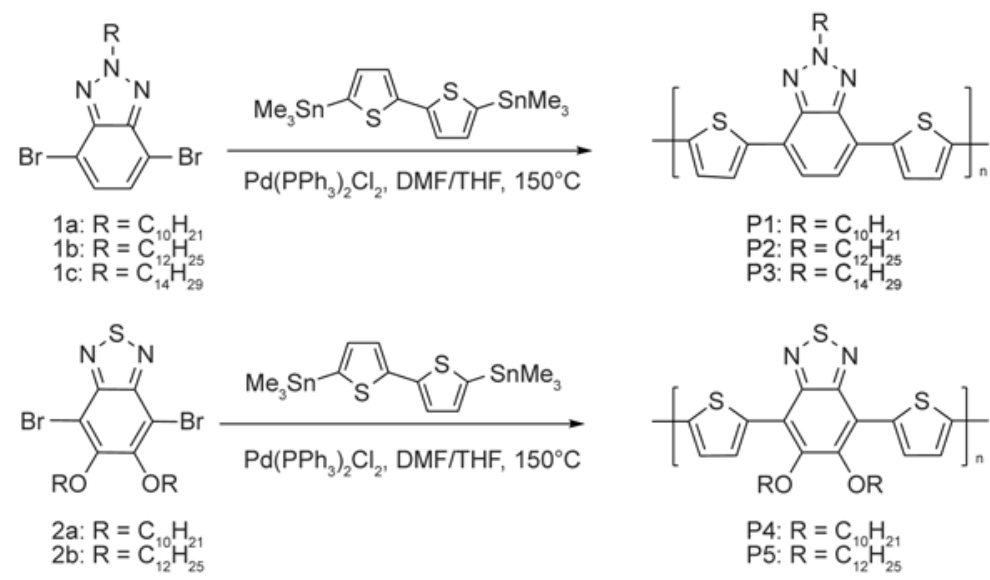

Figure 1. Synthetic routes leading to polymers P1-P5 
Molecular weights were determined using Waters Model 2690 Gel Permeation Chromatography (GPC) in HPLC-grade tetrahydrofuran (THF) against polystyrene (PS) as standard. UV-vis absorption spectra were measured with a Shimadzu UV-3101 PC scanning spectrometer. The fluorescence measurements were conducted with Perkin Elmer LS55 fluorescence spectrometer. Modulated differential scanning calorimetry (DSC 2920) was used to evaluate the thermal behaviors of the polymers. Polymer deposition was carried out using a SCS G3P-8 spincoater, at a speed rate of $1000 \mathrm{rpm}$ for $60 \mathrm{~s}$, to yield film thicknesses of approximately $70-80 \mathrm{~nm}$. An Autolab PGSTAT128N potentiostat/galvanostat was used for cyclic voltammetry experiments and in situ spectroelectrochemical studies. A Shimadzu UV-3600 UVvis-NIR spectrophotometer was also employed for the spectroelectrochemical studies.

\subsection{Synthesis of monomers}

Dibromo-benzotriazole monomers 1a-1c, 4,7dibromo-5,6-dialkoxy-benzothiadiazole monomers 2a-2b and the monomer 5,5'-bis(trimethylstannyl)2,2'-bithiophene were prepared according to the reported procedures $[39,40,43]$.

\section{4,7-Dibromo-2-decylbenzotriazole (1a)}

Yield 50\%; ${ }^{1} \mathrm{H}-\mathrm{NMR}\left(\mathrm{CDCl}_{3}, 400 \mathrm{MHz}\right): \delta \mathrm{ppm}=$ $7.44(\mathrm{~s}, 2 \mathrm{H}), 4.78(\mathrm{t}, J=7.2,7.6 \mathrm{~Hz}, 2 \mathrm{H}), 2.15(\mathrm{~m}$, $2 \mathrm{H}), 1.37-1.25(\mathrm{~m}, 14 \mathrm{H}), 0.88(\mathrm{t}, J=6.8 \mathrm{~Hz}, 3 \mathrm{H})$; ${ }^{13} \mathrm{C}-\mathrm{NMR}\left(100 \mathrm{MHz}, \mathrm{CDCl}_{3}\right): \delta=144.1,129.8$, $110.3,57.8,32.2,30.5,29.74,29.65,29.54,29.28$, 26.83, 22.95, 14.4; MS (EI): calc for $\mathrm{C}_{16} \mathrm{H}_{23} \mathrm{Br}_{2} \mathrm{~N}_{3}$ $[\mathrm{M}]^{+}$417.2, found 416.8 .

\section{4,7-Dibromo-2-dodecylbenzotriazole (1b)}

Yield 62\%; ${ }^{1} \mathrm{H}-\mathrm{NMR}\left(\mathrm{CDCl}_{3}, 400 \mathrm{MHz}\right): \delta \mathrm{ppm}=$ $7.44(\mathrm{~s}, 2 \mathrm{H}), 4.78(\mathrm{t}, J=7.2,7.6 \mathrm{~Hz}, 2 \mathrm{H}), 2.15(\mathrm{~m}$, $2 \mathrm{H}), 1.36-1.25(\mathrm{~m}, 18 \mathrm{H}), 0.88(\mathrm{t}, J=6.8 \mathrm{~Hz}, 3 \mathrm{H})$.

\section{4,7-Dibromo-2-tetradecylbenzotriazole (1c)}

Yield $45 \%$; ${ }^{1} \mathrm{H}-\mathrm{NMR}\left(\mathrm{CDCl}_{3}, 400 \mathrm{MHz}\right): \delta \mathrm{ppm}=$ 7.44 (s, 2H), 4.77 (t, $J=7.2,7.6 \mathrm{~Hz}, 2 \mathrm{H}), 2.15$ (m, $2 \mathrm{H}), 1.36-1.25(\mathrm{~m}, 22 \mathrm{H}), 0.88(\mathrm{t}, J=6.8 \mathrm{~Hz}, 3 \mathrm{H})$; ${ }^{13} \mathrm{C}-\mathrm{NMR}\left(100 \mathrm{MHz}, \mathrm{CDCl}_{3}\right): \delta=144.1,129.9$, $110.4,57.8,32.3,30.5,30.01,29.98,29.93,29.83$, 29.69, 29.32 26.87, 23.03, 14.4; MS (EI): calc for $\mathrm{C}_{20} \mathrm{H}_{31} \mathrm{Br}_{2} \mathrm{~N}_{3}[\mathrm{M}]^{+} 473.3$, found 472.9 .
4,7-Dibromo-5,6-bis(decyloxy)benzo-2,1,3thiadiazole (2a)

Yield $85 \%$; ${ }^{1} \mathrm{H}-\mathrm{NMR}\left(\mathrm{CDCl}_{3}, 400 \mathrm{MHz}\right): \delta \mathrm{ppm}=$ $4.16(\mathrm{t}, J=6.4 \mathrm{~Hz}, 4 \mathrm{H}), 1.88(\mathrm{~m}, 4 \mathrm{H}), 1.28(\mathrm{~m}, 28 \mathrm{H})$, 0.89 (t, $J=6.4 \mathrm{~Hz}, 6 \mathrm{H}) ;{ }^{13} \mathrm{C}-\mathrm{NMR}(100 \mathrm{MHz}$, $\left.\mathrm{CDCl}_{3}\right): \delta=154.9,150.8,106.6,75.5,32.3,30.6$, 29.96, 29.94, 29.79, 29.68, 26.4, 23.04, 14.4; MS (EI): calc for $\mathrm{C}_{26} \mathrm{H}_{42} \mathrm{Br}_{2} \mathrm{~N}_{2} \mathrm{O}_{2} \mathrm{~S}[\mathrm{M}]^{+} 606.5$, found 606.1 .

\section{4,7-Dibromo-5,6-bis(dodecyloxy)benzo-2,1,3-}

thiadiazole (2b)

Yield $88 \%$; ${ }^{1} \mathrm{H}-\mathrm{NMR}\left(\mathrm{CDCl}_{3}, 400 \mathrm{MHz}\right): \delta \mathrm{ppm}=$ $4.16(\mathrm{t}, J=6.8,6.4 \mathrm{~Hz}, 4 \mathrm{H}), 1.88(\mathrm{~m}, 4 \mathrm{H}), 1.27(\mathrm{~m}$, $36 \mathrm{H}), 0.88(\mathrm{t}, J=6.8,6.4 \mathrm{~Hz}, 6 \mathrm{H}) ;{ }^{13} \mathrm{C}-\mathrm{NMR}$ $\left(100 \mathrm{MHz}, \mathrm{CDCl}_{3}\right): \delta=154.9,150.8,106.6,75.5$, $32.3,30.64,30.04,30.01,29.99,29.80,29.72$, 29.39, 26.4, 23.04, 14.4; MS (EI): calc for $\mathrm{C}_{30} \mathrm{H}_{50} \mathrm{Br}_{2} \mathrm{~N}_{2} \mathrm{O}_{2} \mathrm{~S}[\mathrm{M}]^{+}$662.6, found 662.2.

\subsection{Synthesis of polymers (P1-P5)}

Compound 1a-1c $(2 \mathrm{mmol})$ or $\mathbf{2 a - 2 b}(2 \mathrm{mmol})$ and 5,5'-bis(trimethylstannyl)-2,2'-bithiophene (2 mmol) were dissolved in $50 \mathrm{~mL}$ dry DMF and $50 \mathrm{~mL}$ dry THF, which was purged with argon for $1 \mathrm{~h}$. $\mathrm{Pd}\left(\mathrm{PPh}_{3}\right)_{2} \mathrm{Cl}_{2}(30 \mathrm{mg})$ was added in one portion and the mixture was heated up to reflux at $150^{\circ} \mathrm{C}$ for 4 days. After cooling down to room temperature, the solvents were evaporated under reduced pressure and the residue was dissolved by small amount of hot chloroform, followed by precipitation in cold methanol. The resulting black particles after filtration were then purified by Soxhlet extraction with successively $\mathrm{MeOH}$, hexane, and chlorobenzene. The chlorobenzene fraction was recovered and evaporated and the dark purple solid was obtained.

Polymer P1 Poly\{2-decyl-4,7-di(thiophen-2-yl)-

2H-benzo[d][1,2,3]triazole\}

(Yield, 76\%). ${ }^{1} \mathrm{H}-\mathrm{NMR}\left(\mathrm{CDCl}_{3}, 400 \mathrm{MHz}\right): \delta \mathrm{ppm}=$ $7.53(\mathrm{~m})$ (benzotriazole), 7.37 (br) (thiophene), 7.07 (br) (thiophene), 4.86 (br) (-N- $\left.\mathrm{CH}_{2}-\right), 1.68-0.87$ (br) (pendant alkyl chain). GPC using PS in THF as standard: $\left(M_{\mathrm{n}}=35.1 \mathrm{k}, M_{\mathrm{w}}=49.5 \mathrm{k}\right.$, PDI $\left.=1.41\right)$; Anal. Calcd. for P1: $\left(\mathrm{C}_{24} \mathrm{H}_{27} \mathrm{~N}_{3} \mathrm{~S}_{2}\right)_{\mathrm{n}}: \mathrm{C}, 68.37 ; \mathrm{H}, 6.45 ; \mathrm{N}$, 9.97. Found: C $68.06 ; \mathrm{H}, 6.77 ; \mathrm{N}, 10.05$. 
Polymer P2 Poly\{2-dodecyl-4,7-di(thiophen-2-yl)2H-benzo[d][1,2,3]triazole\}

(Yield, 64\%). ${ }^{1} \mathrm{H}-\mathrm{NMR}\left(\mathrm{CDCl}_{3}, 400 \mathrm{MHz}\right): \delta \mathrm{ppm}=$ 7.59-7.70 (benzotriazole), 7.33-7.45 (thiophene), 7.00-7.13 (thiophene), 4.72-4.87 (-N- $\left.\mathrm{CH}_{2}-\right), 1.53-$ 0.83 (pendant alkyl chain). GPC using PS in THF as standard: $\left(M_{\mathrm{n}}=119.5 \mathrm{k}, M_{\mathrm{w}}=157.1 \mathrm{k}, \mathrm{PDI}=1.31\right)$; Anal. Calcd. for P2: $\left(\mathrm{C}_{26} \mathrm{H}_{31} \mathrm{~N}_{3} \mathrm{~S}_{2}\right)_{\mathrm{n}}$ : C, 69.45; H, $6.95 ;$ N, 9.34. Found: C 69.36; H, 7.17; N, 9.15.

\section{Polymer P3 Poly\{2-tetradecyl-4,7-di(thiophen-2- yl)-2H-benzo[d][1,2,3]triazole\} \\ (Yield, $72 \%) .{ }^{1} \mathrm{H}-\mathrm{NMR}\left(\mathrm{CDCl}_{3}, 400 \mathrm{MHz}\right): \delta \mathrm{ppm}=$ 7.60-7.78 (benzotriazole), 7.22-7.35 (thiophene), 7.09-7.15 (thiophene), 4.78-4.89 (-N- $\left.\mathrm{CH}_{2}-\right), 1.69-$ 0.82 (pendant alkyl chain). GPC using PS in THF as standard: $\left(M_{\mathrm{n}}=26.7 \mathrm{k}, M_{\mathrm{w}}=45.2 \mathrm{k}, 1.70\right)$; Anal. Calcd. for P3: $\left(\mathrm{C}_{28} \mathrm{H}_{35} \mathrm{~N}_{3} \mathrm{~S}_{2}\right)_{\mathrm{n}}$ : C, 70.40; H, 7.38; N, 8.80. Found: C 70.26; H, 7.57; N, 8.65.}

Polymer P4 Poly\{5,6-bis(decyloxy)-4, 7di(thiophen-2-yl)benzo[c][1,2,5]thiadiazole\} (Yield, 65\%). ${ }^{1} \mathrm{H}-\mathrm{NMR}\left(\mathrm{CDCl}_{3}, 400 \mathrm{MHz}\right): \delta \mathrm{ppm}=$ $8.6(\mathrm{~m}), 7.4(\mathrm{~m}), 4.2(\mathrm{~m}), 2.04-1.12(\mathrm{~m}), 0.88(\mathrm{~m})$. GPC using PS in THF as standard: $\left(M_{\mathrm{n}}=32.9 \mathrm{k}\right.$, $M_{\mathrm{w}}=55.8 \mathrm{k}$, PDI $=1.70$ ); Anal. Calcd. for $\mathbf{P} 4$ : $\left(\mathrm{C}_{34} \mathrm{H}_{46} \mathrm{~N}_{2} \mathrm{O}_{2} \mathrm{~S}_{3}\right)_{\mathrm{n}}$ : C, 66.84; H, 7.59; N, 4.59. Found: C $66.61 ; \mathrm{H}, 7.83 ; \mathrm{N}, 4.50$.

Polymer P5 Poly\{5,6-bis(dodecyloxy)-4,7di(thiophen-2-yl)benzo[c][1,2,5]thiadiazole\} (Yield 61\%). ${ }^{1} \mathrm{H}-\mathrm{NMR}\left(\mathrm{CDCl}_{3}, 400 \mathrm{MHz}\right): \delta \mathrm{ppm}=$ $8.6(\mathrm{~m}), 7.4(\mathrm{~m}), 4.2(\mathrm{~m}), 2.03-1.11(\mathrm{~m}), 0.86(\mathrm{~m})$. GPC using PS in THF as standard: $\left(M_{\mathrm{n}}=33.3 \mathrm{k}\right.$, $M_{\mathrm{w}}=61.9 \mathrm{k}$, PDI $\left.=1.90\right)$; Anal. Calcd. for P5: $\left(\mathrm{C}_{38} \mathrm{H}_{56} \mathrm{~N}_{2} \mathrm{O}_{2} \mathrm{~S}_{3}\right)_{n}$ : C, 68.42; H, 8.16; N, 4.20. Found: C 68.72; H, 8.40; N, 4.13.

\subsection{Cyclic voltammetry}

The polymer solutions in $m$-xylene $(10 \mathrm{mg} / \mathrm{mL})$ were drop cast $(2 \mu \mathrm{L})$ onto glassy carbon electrode to form electrochromic layers with an active area of around $0.03 \mathrm{~cm}^{2}$. Cyclic voltammetry $(\mathrm{CV})$ was performed in a three-electrode cell with polymer-coated glassy carbon electrode (CH Instruments, $2 \mathrm{~mm}$ diameter) as the working electrode, platinum wire (CH Instruments) as the counter electrode and silver wire (CH Instruments) as the reference electrode. A $0.1 \mathrm{M} \mathrm{LiClO}_{4}$ solution in acetonitrile was used. For $\mathrm{CV}$ measurements, the electrolyte solution was first bubbled with argon for $60 \mathrm{~min}$ to remove residual oxygen prior to characterization. A scan rate of $25 \mathrm{mV} / \mathrm{s}$ was employed for the studies. The pseudoreference electrode was calibrated with respect to the ferrocene/ferrocenium redox couple $E_{1 / 2}$ $\left(\mathrm{Fc} / \mathrm{Fc}^{+}\right)=+0.29 \mathrm{~V}$ (vs. Ag wire). For the approximation of HOMO levels, the ferrocene/ferrocenium redox couple was taken to occur at $4.8 \mathrm{eV}$ below vacuum.

\subsection{Spectroelectrochemistry}

The solutions of $\mathbf{P 1}$ to $\mathbf{P 5}$ in $m$-xylene $(10 \mathrm{mg} / \mathrm{mL})$ were spin-coated (1000 rpm, $60 \mathrm{~s}$ ) onto ITO coated PET to form electrochromic layers with an active area of $2.5 \mathrm{~cm}^{2}$. In-situ spectroelectrochemical data for the polymer thin film were recorded using a threeelectrode cell assembly, where the working electrode was the ITO coated PET substrate, the counter electrode was a platinum wire and a $\mathrm{Ag}$ wire was the pseudo-reference electrode. A $0.1 \mathrm{M} \mathrm{LiClO}_{4}$ solution in acetonitrile was used as prepared. The spectra were scanned after the potentials have been applied for $10 \mathrm{~s}$, and held throughout the course of the scans.

\subsection{Computational details}

All theoretical calculations were carried out at the density functional theory (DFT) level with the B3LYP functional and the 6-31G(d) basis set using Gaussian 09 [44]. The vertical energy transition data and oscillator strengths were obtained by the timedependent density functional theory (TD-DFT). Gauss View was used to generate the pictorial representations.

\section{Results and discussion 3.1. Synthesis}

The synthesis of the target polymers P1-P5 is shown in Figure 1. The Stille cross coupling reaction was utilized as the polymerization tool to construct the copolymers P1-P5. All the five polymers were obtained in satisfactory yields and exhibited good solubility in common organic solvents such as chloroform and chlorobenzene. The molecular weight and polydispersity index of the synthesized polymers P1-P5 are summarized in Table 1. Stille coupling reaction has been validated as a reliable polymerization technique to prepare conjugated copolymers with high molecular weight and low polydispersity compared to Yomamoto coupling reaction, chemi- 
Table 1. Molecular weights and polydispersity of polymers P1-P5

\begin{tabular}{|c|c|c|c|}
\hline Polymer & $\begin{array}{c}\mathbf{M}_{\mathbf{w}} \\
{[\mathbf{D a}]}\end{array}$ & $\begin{array}{c}\mathbf{M}_{\mathbf{n}} \\
{[\mathbf{D a}]}\end{array}$ & $\begin{array}{c}\text { Polydispersity } \\
\text { index }\end{array}$ \\
\hline P1 & 49500 & 35100 & 1.41 \\
\hline P2 & 157100 & 119500 & 1.31 \\
\hline P3 & 45200 & 26700 & 1.70 \\
\hline P4 & 55800 & 32900 & 1.70 \\
\hline P5 & 61900 & 33300 & 1.90 \\
\hline
\end{tabular}

${ }^{\mathrm{a}} M_{\mathrm{w}}$ : the weight-average molecular weight. $M_{\mathrm{n}}$ : the number-average molecular weight.

cal oxidative polymerization or electrochemical polymerization methods [45-48]. As a representation of the polymers, $\mathbf{P 2}$ and P5 were chosen for the probing of the thermal stabilities. The polymers exhibit good thermal stability and no phase transition peaks are observed by differential scanning calorimetry study up to $200^{\circ} \mathrm{C}$. The polymers also reveal high solubility in common organic solvents such as chloroform, toluene and xylene.

\subsection{Optical properties}

The UV-visible absorption and photoluminescence spectra of polymers P1-P5 are plotted in Figure 2 and the results for all polymers are summarized in Table 2. As representative examples, the insert pictures in Figure 2 show the absorption and emission colour of the THF solutions of P2 and P5. For P1 to $\mathbf{P 3}$, as the length of the alkyl chains increases from octyl $\left(-\mathrm{C}_{8} \mathrm{H}_{17}\right)$ to dodecyl $\left(-\mathrm{C}_{12} \mathrm{H}_{25}\right)$, the absorption maximum remained essentially the same both in the solution $(\sim 500 \mathrm{~nm})$ and in the film $(\sim 490 \mathrm{~nm})$ while the absorption onset showed a slight bathochromic shift from $635 \mathrm{~nm}$ for $\mathbf{P 1}$ to $653 \mathrm{~nm}$ for P3, indicating that variation of the aliphatic chains has mini- mal influence on the absorption behaviour of the polymers [49]. The absorption maxima of P4 and P5 is about $90 \mathrm{~nm}$ red shifted compared with those of P1-P3, mainly due to a stronger electron withdrawing ability of 5,6-dialkoxy-benzothiadiazole compared with benzotriazole. It is worthy to note that the series of benzotriazole based polymers (P1-P3) showed a bright orange emission with quantum yield of 0.4-0.6 while two dialkoxy-benzothiadiazole based polymers (P4 and P5) exhibited low quantum yield of $<0.1$. This could perhaps be attributed to the presence of two long alkoxy chains in P4 and P5 which disrupt the planarity of the conjugated backbone. In highly rigid conjugated systems, high quantum yields have been observed [50]. The bright fluorescence of $\mathbf{P 1 - P 3}$ rendered them potential as fluorescence based sensing materials [51].

\subsection{Electrochemical and spectroelectrochemical behavior}

The redox behaviours of the polymers were studied using cyclic voltammetry and the results are summarized in Table 2. Typical cyclic voltammograms of $\mathbf{P 2}$ and P5 are shown in Figure 3 as representation. The cyclic voltammograms of the other polymers can be found in the supporting information. P1-P3 exhibited similar HOMO $(\sim-5.4 \mathrm{eV})$ and LUMO $(\sim-3.4 \mathrm{eV})$ energy levels. For P4 and P5, the HOMO are slightly lower than that of P1-P3. This is mainly ascribed to the higher electron affinity of 5,6dialkoxy-benzothiadiazole than benzotriazole moiety (vide infra). Length of the alkyl chains attached was found to have minimal influence on the electronic behavior of the polymers.
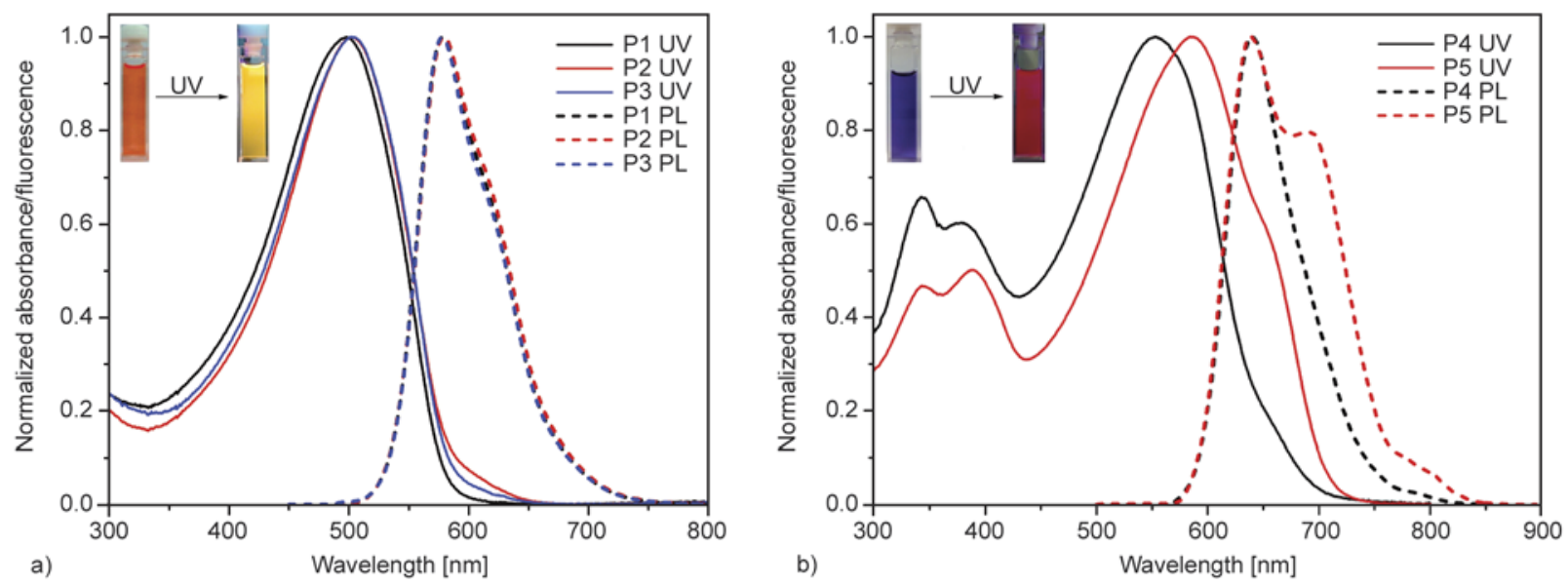

Figure 2. Absorption and emission spectra of (a) P1-P3 and (b) P4 and P5 in THF. The inserts show the color of P2 and P5 in THF solution under white light (left) and when exposed to UV light (366 nm) (right) at ambient temperature. 
Table 2. Optical and electrochemical properties of polymers P1-P5

\begin{tabular}{|c|c|c|c|c|c|c|c|}
\hline Polymer & $\begin{array}{c}\lambda_{\max }(\mathbf{T H F})^{\mathbf{a}} \\
{[\mathbf{n m}]}\end{array}$ & $\begin{array}{c}\lambda_{\max }(\mathbf{e m})^{\mathbf{b}} \\
{[\mathbf{n m}]}\end{array}$ & $\begin{array}{c}\lambda_{\text {onset }}(\mathbf{f i l m})^{\mathbf{c}} \\
{[\mathbf{n m}]}\end{array}$ & $\begin{array}{c}\mathbf{E}_{\mathbf{g}}^{\mathbf{o p d}} \\
{[\mathbf{e V}]}\end{array}$ & $\begin{array}{c}\mathbf{H O M O}^{\mathbf{e}} \\
{[\mathbf{e V}]}\end{array}$ & $\begin{array}{c}\mathbf{L U M O}^{\mathbf{f}} \\
{[\mathbf{e V}]}\end{array}$ & $\mathbf{\Phi}_{\mathbf{P L}}(\mathbf{T H F})^{\mathbf{g}}$ \\
\hline $\mathbf{P 1}$ & 497 & 578.5 & 635 & 1.95 & -5.35 & -3.40 & 0.60 \\
\hline $\mathbf{P 2}$ & 501 & 579.0 & 645 & 1.92 & -5.35 & -3.43 & 0.42 \\
\hline $\mathbf{P 3}$ & 501 & 578.5 & 653 & 1.90 & -5.37 & -3.47 & 0.62 \\
\hline $\mathbf{P 4}$ & 586 & 638.5 & 696 & 1.78 & -5.49 & -3.71 & 0.10 \\
\hline P5 & 586 & 639.0 & 710 & 1.75 & -5.37 & -3.62 & 0.02 \\
\hline
\end{tabular}

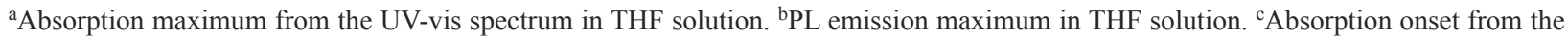
UV-vis spectrum. ${ }^{\mathrm{d}}$ Egop is calculated following the equation $E_{\mathrm{g}}{ }^{\mathrm{op}}=1240 / \lambda_{\text {onset }}[\mathrm{eV}]$; ${ }^{\mathrm{e}} \mathrm{HOMO}$ is calculated following the equation $\mathrm{HOMO}=-\left(4.8+E_{\text {onset }^{\mathrm{ox}}} \mathrm{vs} \mathrm{Fc} / \mathrm{Fc}^{+}\right) .{ }^{\mathrm{f}} \mathrm{LUMO}$ is calculated following the equation LUMO $=\mathrm{HOMO}-E_{\mathrm{g}}{ }^{\text {op }}$. ${ }^{\mathrm{d}} \mathrm{The}$ photoluminescence $(P L)$ quantum yield $\left(\Phi_{\mathrm{PL}}\right)$ of the polymer in THF solution was measured by using quinine sulphate (ca. $1 \cdot 10^{-5} \mathrm{M}$ solution in $0.1 \mathrm{M} \mathrm{H}_{2} \mathrm{SO}_{4}$, assuming $\Phi_{\mathrm{PL}}$ of 0.55 ) as a standard.
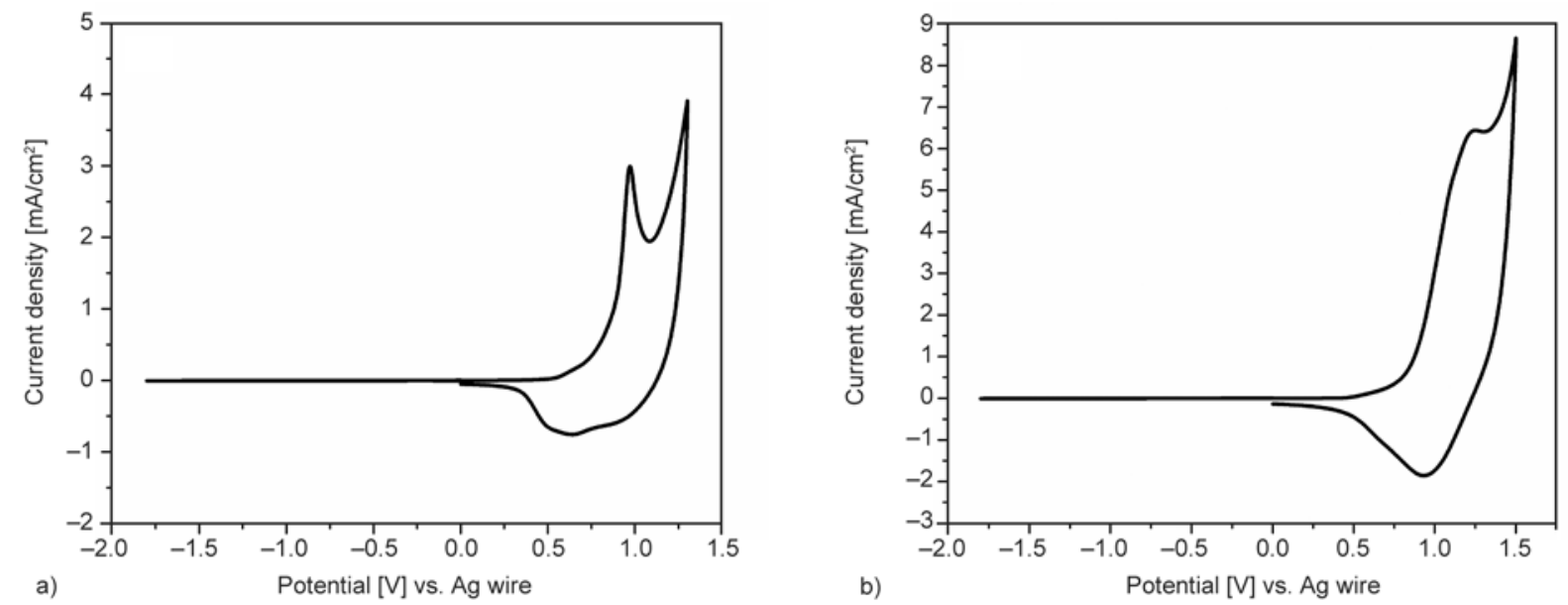

Figure 3. Cyclic voltammograms of (a) $\mathbf{P 2}$ and (b) $\mathbf{P 5}$ films in $0.1 \mathrm{M} \mathrm{LiClO}_{4}$ solution in acetonitrile at a scan rate of $25 \mathrm{mV} / \mathrm{s}$

The electrochemical absorption spectra of the polymers were recorded upon progressive oxidation from 0.0 to around $1.5 \mathrm{~V}$. At the neutral states, polymers P1 to P5 all reveal one broad absorption band in the visible region with absorption maximum of around 500-600 $\mathrm{nm}$. The benzotriazole-based polymers P1-P3 display a purple hue in their neutral states, whereas the benzothiadiazole-based poly-

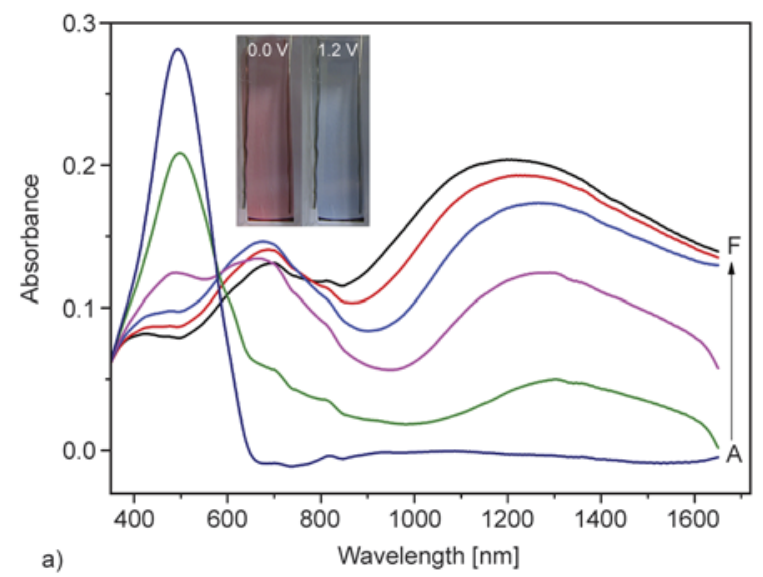

mers $\mathbf{P} 4$ and $\mathbf{P 5}$ are blue. As the polymers are gradually oxidized, the peaks at the visible region decrease while polaronic and bipolaronic bands start to appear in the NIR region. At the fully oxidized state, all the polymers turn transmissive blue due to the tailing absorption in the visible region. The color changes observed for the polymers are depicted in Figure 4. Such colored-to-transmissive electro-

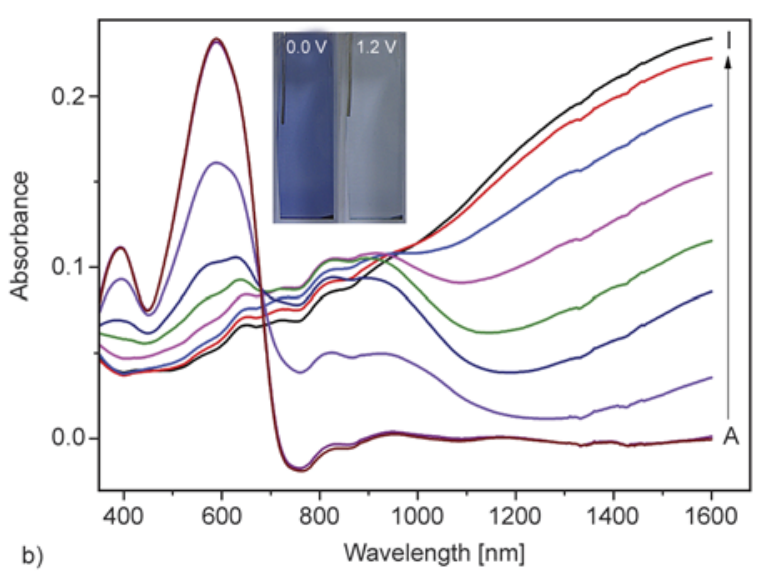

Figure 4. Spectroelectrochemistry of (a) P2 and (b) P5 film on an ITO coated PET in 0.1 $\mathrm{M} \mathrm{LiClO}_{4}$ solution in acetonitrile at applied potentials [V]. Curves: (A) 0.0, (B) 0.5, (C) 0.8, (D) 1.0, (E) 1.1, (F) 1.2, (G) 1.3, (H) 1.4, (I) $1.5 \mathrm{~V}$. Inserts show the colors of (a) P2 and (b) P5 films at $0.0 \mathrm{~V}$ and $1.2 \mathrm{~V}$. 
chromic changes are of particular interest in absorption/transmission devices such as smart windows, information displays etc [1].

\subsection{TD-DFT computational analysis}

To better understand the electronic properties of these two series of polymers, time-dependent density functional theory (TD-DFT at the B3LYP/6$31 \mathrm{G}(\mathrm{d})$ level) calculations were carried out for the oligomeric model compounds of these polymers. All the side chains are shortened to methyl groups in the model compounds to save calculation time as it has been found that the length of alkyl chains has minimal influence on the electronic properties of the polymers. The optimized structures and the HOMO/ LUMO profiles of the trimeric model compounds of P1-P5 are shown in Figure 5. Both frontier orbitals are found to distribute evenly over the whole conjugated system. It is noted that the -NR group in the benzotriazole moiety and the $\mathrm{S}$ atom in the 5,6dialkoxy-benzothiadiazole moiety are only covered by the LUMO and the sulfur atom is more intensively involved in the LUMO electron density compared with the -NR moiety, which would be due to the larger polarizability of sulfur atom [37]. One more feature to highlight is the phase distribution of the HOMO and LUMO in the conjugated backbone. In the HOMO profile, the two carbons linking the thiophene and the acceptor unit is in the opposite phase while in the LUMO profile, these two carbons are in the same phase. Such patterns have been routinely observed in many $\mathrm{D}-\mathrm{A}$ type conjugated systems [52-55], and this suggests that both the donor and the acceptor play an essential role in determining the energy levels. The energy levels of the HOMO and LUMO orbitals were computed for the monomer, dimer and oligomers, and the band gaps are plotted as a function of the inverse of the number of repeating monomer units [56, 57]. Through extrapolation of the curve, the estimated band gap of an infinitely long polymer chain is obtained (Table 3 ). It is estimated that the band gap of the 5,6-dialkoxy-
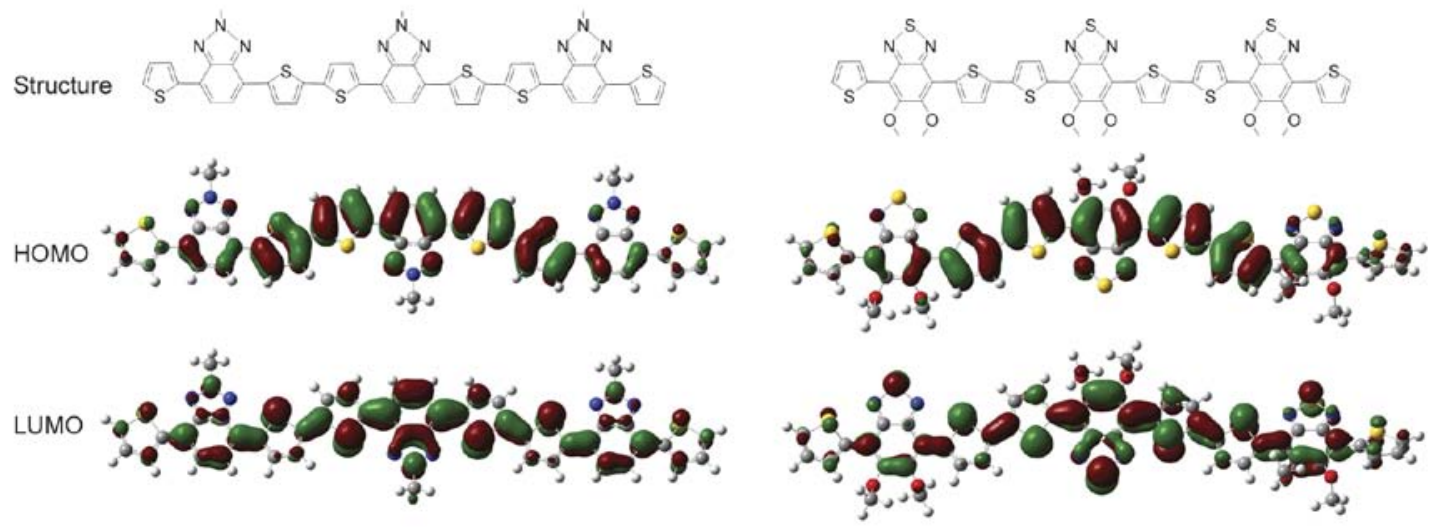

Figure 5. Electron distribution in HOMO and LUMO orbitals of benzotriazole and 5,6-dialkoxy-benzothiadiazole-based trimers

Table 3. TD-DFT calculated HOMO/LUMO energy levels of benzotriazole and 5,6-dialkoxy-benzothiadiazole based oligomers

\begin{tabular}{|c|c|c|c|c|}
\hline Chemical structure & $\mathbf{N}$ & $\begin{array}{c}\text { HOMO } \\
{[\mathrm{eV}]}\end{array}$ & $\begin{array}{c}\text { LUMO } \\
{[\mathrm{eV}]}\end{array}$ & $\begin{array}{c}\mathbf{E}_{\mathrm{g}} \\
{[\mathrm{eV}]}\end{array}$ \\
\hline \multirow{5}{*}{$\mathrm{H}+\mathrm{L}$} & 1 & -5.094 & -1.903 & 3.192 \\
\hline & 2 & -4.672 & -2.233 & 2.439 \\
\hline & 3 & -4.544 & -2.361 & 2.183 \\
\hline & 4 & -4.489 & -2.422 & 2.067 \\
\hline & $\infty$ & - & - & 1.686 \\
\hline & 1 & -5.276 & -2.432 & 2.844 \\
\hline & 2 & -4.831 & -2.613 & 2.217 \\
\hline & 3 & -4.699 & -2.700 & 1.999 \\
\hline & 4 & -4.646 & -2.739 & 1.907 \\
\hline $\mathrm{O}_{1}$ & $\infty$ & - & - & 1.587 \\
\hline
\end{tabular}


benzothiadiazole based polymer $(1.59 \mathrm{eV})$ is about $0.1 \mathrm{eV}$ less than that of the benzotriazole based polymer $(1.69 \mathrm{eV})$. This trend is in agreement with the experimental measurement. The electron-accepting ability of the benzotriazole and 5,6-dialkoxy-benzothiadiazole units is compared using the LUMO energy levels as a crude approximation. The LUMO level of the benzotriazole based monomer is calculated to be around $-1.903 \mathrm{eV}$ which is $0.5 \mathrm{eV}$ higher than that of the 5,6-dialkoxy-benzothiadiazole based monomer at $-2.432 \mathrm{eV}$, hence confirming the weaker electron affinity of the benzotriazole based monomer.

\subsection{Electrochromic performance}

A square-wave potential step absorptometry was carried out to characterize the degree of color changes of the polymers. The potentials were switched repeatedly between 1.2 and $-1.2 \mathrm{~V}$ with a switching time of $10 \mathrm{~s}$ for 2 cycles, $5 \mathrm{~s}$ for 4 cycles, $2 \mathrm{~s}$ for 6 cycles and $1 \mathrm{~s}$ for 8 cycles at the absorption maximum in both the visible and NIR regions. The results are shown in Figure 6 and summarized in Table 4. Respectable contrasts were recorded for the poly-

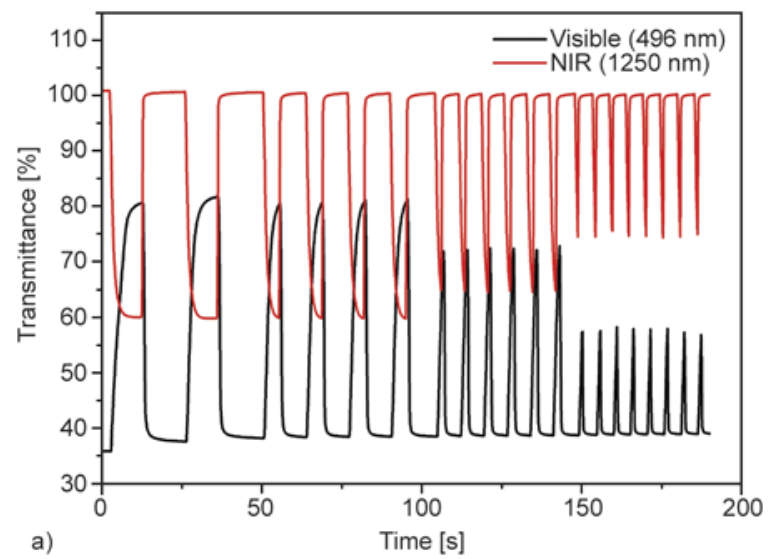

mers in the visible and NIR regions respectively. Among all the polymers, $\mathbf{P 2}$ displayed the most promising contrasts of about $40 \%$ in both the visible and NIR regions. It was also found that the length of side chains influences the electrochromic performance to a considerable extent. Across the two series of polymers, it is interesting to note that the polymers with alkyl/alkoxy chain lengths of twelve carbon units appear to yield the best electrochromic performance. Further studies may involve the study and elucidation of the structure of side chains necessary to yield devices with optimal performances. In comparison to a similar polymer with a benzyl side group functionalized at the benzotriazole instead of an alkyl chain in this work, similar contrast in the visible region was observed [58]. The response times of the polymers were calculated as the time required to achieve $95 \%$ optical contrast of the full switch. This value is typically used as the human eye is unable to discern the difference in the last 5\% [1]. The coloration and bleaching time in the visible and NIR regions for all the polymers are determined and given in Table 4. Among the benzotriazole and

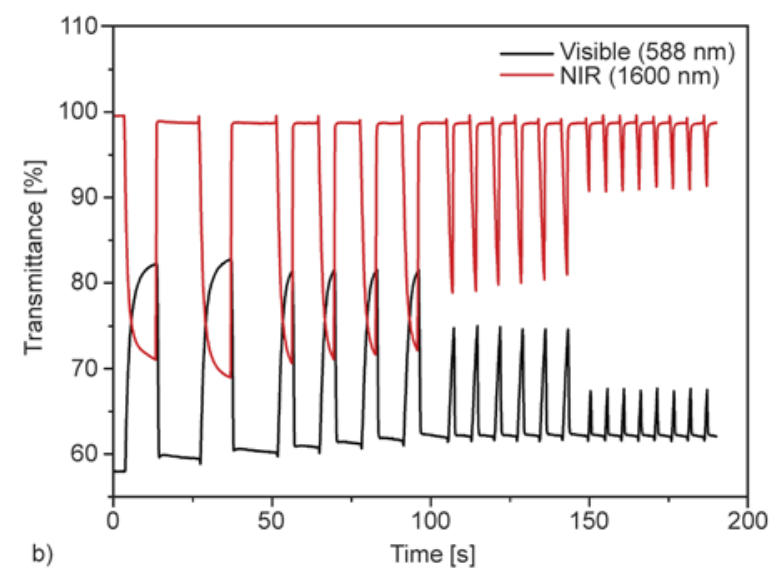

Figure 6. Square-wave potential step absorptometry of (a) P2 and (b) P5 film in the visible region and NIR region on an ITO coated PET in $0.1 \mathrm{M} \mathrm{LiClO}_{4} / \mathrm{ACN}$ electrolyte/solvent couple between $-1.2 \mathrm{~V}$ and $1.2 \mathrm{~V}$ with a switch time of $10 \mathrm{~s}$ for 2 cycles, $5 \mathrm{~s}$ for 4 cycles, $2 \mathrm{~s}$ for 6 cycles and $1 \mathrm{~s}$ for 8 cycles

Table 4. Summary of electrochromic performance of polymers P1-P5 in film state

\begin{tabular}{|c|c|c|c|c|c|c|c|c|}
\hline \multirow{3}{*}{ Polymer } & \multicolumn{2}{|c|}{$\begin{array}{c}\text { Optical contrast } \\
{[\Delta T \%]}\end{array}$} & \multicolumn{4}{|c|}{$\begin{array}{c}\text { Switching time } \\
{[\mathrm{s}]}\end{array}$} & \multicolumn{2}{|c|}{$\begin{array}{c}\text { Coloration efficiency } \\
{\left[\mathrm{cm}^{2} / \mathrm{C}\right]}\end{array}$} \\
\hline & \multirow[b]{2}{*}{ At $\lambda_{\max }$} & \multirow{2}{*}{ At NIR } & \multicolumn{2}{|c|}{ At $\lambda_{\max }$} & \multicolumn{2}{|c|}{ At NIR } & \multirow[b]{2}{*}{ At $\lambda_{\max }$} & \multirow{2}{*}{ At NIR } \\
\hline & & & Coloration $^{\mathrm{a}}$ & Bleaching & Coloration & Bleaching ${ }^{\mathrm{b}}$ & & \\
\hline P1 & 22 & 25 & 1.2 & 3.2 & 2.9 & 0.8 & 191 & 234 \\
\hline P2 & 44 & 40 & 0.8 & 5.0 & 2.5 & 0.4 & 518 & 561 \\
\hline P3 & 23 & 24 & 1.3 & 1.3 & 1.2 & 0.9 & 273 & 333 \\
\hline P4 & 14 & 22 & 0.4 & 2.4 & 4.0 & 0.4 & 230 & 257 \\
\hline P5 & 23 & 30 & 0.6 & 5.4 & 5.0 & 0.3 & 403 & 275 \\
\hline
\end{tabular}

${ }^{a}$ Coloration refers to the process in which the percent transmittance changes from a higher value to lower value; ${ }^{b}$ Bleaching refers to the process in which the percent transmittance changes from a lower value to higher value. 
5,6-dialkoxy-benzothiadiazole based polymers, $\mathbf{P 2}$ exhibits the best switching behaviour during bleaching in the NIR region at $0.4 \mathrm{~s}$. For all the five polymers, the oxidation process corresponding to the bleaching in the visible region and coloration in the NIR region is found to be slower than the reverse process corresponding to the coloration in the visible region and bleaching in the NIR region. This can be rationally explained by the different diffusion rates of the counter anions $\left(\mathrm{ClO}_{4}^{-}\right)$and counter cations $\left(\mathrm{Li}^{+}\right)$at different charged states of the polymer films [59]. The polymers were subjected to repeated potential switching between 1.2 and $-1.2 \mathrm{~V}$ at $5 \mathrm{~s}$ switch. All the five polymers exhibited stable cycling behavior in the device and the stability cycling performance of $\mathbf{P 2}$ is illustrated in Figure 7 as a demonstration. After about 200 cycling, the polymer film was still able to produce $90 \%$ of the original transmittance with switch time almost unchanged, indicating the high robustness of these copolymers under ambient conditions. The coloration efficiency is estimated from Equation (1) [60]:

$C E(\eta)=\frac{\log \left(\frac{T_{\text {ox }}}{T_{\text {red }}}\right)}{Q_{\mathrm{d}}}$

where $T_{\text {ox }}$ refers to the percent transmittance of the bleached state, $T_{\text {red }}$ the percent transmittance of the colored state, and $Q_{\mathrm{d}}$ the injected/ejected charge per unit area $\left(\mathrm{C} / \mathrm{cm}^{2}\right)$. The coloration efficiency for all the polymers the visible and NIR regions are calculated and tabulated in Table 4. Among all the polymers, $\mathbf{P} \mathbf{2}$ reveals the best coloration efficiency of

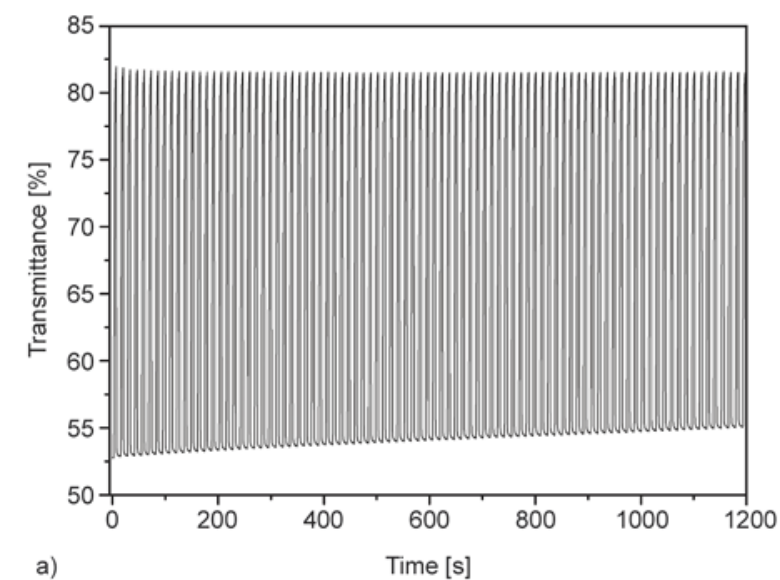

more than $500 \mathrm{~cm}^{2} / \mathrm{C}$ in both visible and NIR regions. In general, the superior electrochromic performance for P1-P3 compared to P4-P5 may have arisen from the lower HOMO levels of P1-P3, which allows for ease of oxidation, lower working voltage and lower energy consumption.

\section{Conclusions}

Two series of benzotriazole and 5,6-dialkoxy-benzothiadiazole containing D-A type conjugated polymers (P1-P5) were synthesized via Stille coupling, affording magenta and blue polymers in their neutral states and partially transmissive in their oxidized states. All the prepared polymers have good solubility in common organic solvents and the films can thus be prepared by solution based processing methods. The effect of the electron-acceptor strength, as well as alkyl chain lengths on the optical, electrochemical and electrochromic properties of the polymers were also studied. Both theoretically and experimentally, it has been shown that the acceptor strength greatly affects the HOMO energy level and the band gap of the conjugated polymers. These polymers have been demonstrated as electrochromic materials which turn partially transmissive upon pdoping. Good contrast, fast switching, high coloration efficiency and high stability of the EC devices have been established using these polymers as the electrochromic layer, thus rendering promise of these benzotriazole and 5,6-dialkoxy-benzothiadiazole based polymers as high performance colored-totransmissive electrochromes.

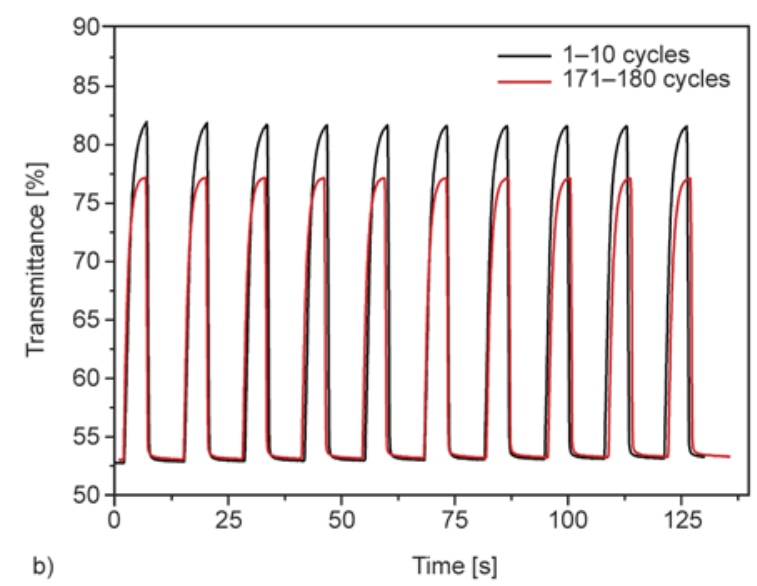

Figure 7. Stability testing of $\mathbf{P} 2$ polymer film through square-wave potential step absorptometry at $\lambda_{\max }$ between 1.2 and $-1.2 \mathrm{~V}$ with a switch time of $5 \mathrm{~s}$, a) illustration of 90 continuous deep cycles, b) comparison in optical contrasts between cycles 1-10 and cycles 171-180 


\section{Acknowledgements}

The authors would like to thank the Agency for Science, Technology and Research (A*STAR) for financial support (Grant no.:1321760011).

\section{References}

[1] Beaujuge P. M., Reynolds J. R.: Color control in $\pi$ conjugated organic polymers for use in electrochromic devices. Chemical Reviews, 110, 268-320 (2010). DOI: $10.1021 / \mathrm{cr} 900129 \mathrm{a}$

[2] Havinga E. E., ten Hoeve W., Wynberg H.: A new class of small band gap organic polymer conductors. Polymer Bulletin, 29, 119-126 (1992).

DOI: $10.1007 / \mathrm{BF} 00558045$

[3] Neto B. A. D., Lapis A. A. M., da Silva Júnior E. N., Dupont J.: 2,1,3-Benzothiadiazole and derivatives: Synthesis, properties, reactions, and applications in light technology of small molecules. European Journal of Organic Chemistry, 2, 228-255 (2013).

DOI: 10.1002/ejoc.201201161

[4] Cheng Y-J., Yang S-H., Hsu C-S.: Synthesis of conjugated polymers for organic solar cell applications. Chemical Reviews, 109, 5868-5923 (2009).

DOI: $10.1021 / \mathrm{cr} 900182 \mathrm{~s}$

[5] Beaujuge P. M., Fréchet J. M. J.: Molecular design and ordering effects in $\pi$-functional materials for transistor and solar cell applications. Journal of the American Chemical Society, 133, 20009-20029 (2011).

DOI: 10.1021/ja2073643

[6] Yen Y-S., Chou H-H., Chen Y-C., Hsu C-Y., Lin J. T.: Recent developments in molecule-based organic materials for dye-sensitized solar cells. Journal of Materials Chemistry, 22, 8734-8747 (2012). DOI: $10.1039 / \mathrm{C} 2 \mathrm{JM} 30362 \mathrm{~K}$

[7] Blouin N., Michaud A., Gendron D., Wakim S., Blair E., Neagu-Plesu R., Belletête M., Durocher G., Tao Y., Leclerc M.: Toward a rational design of poly(2,7-carbazole) derivatives for solar cells. Journal of the American Chemical Society, 130, 732-742 (2008).

DOI: $10.1021 / \mathrm{ja} 0771989$

[8] Wang C., Dong H., Hu W., Liu Y., Zhu D.: Semiconducting $\pi$-conjugated systems in field-effect transistors: A material odyssey of organic electronics. Chemical Reviews, 112, 2208-2267 (2012).

DOI: $10.1021 / \mathrm{cr} 100380 \mathrm{z}$

[9] Biniek L., Schroeder B. C., Nielsen C. B., McCulloch I.: Recent advances in high mobility donor-acceptor semiconducting polymers. Journal of Materials Chemistry, 22, 14803-14813 (2012).

DOI: $10.1039 / \mathrm{C} 2 \mathrm{JM} 31943 \mathrm{H}$

[10] Thakur V. K., Ding G., Ma J., Lee P. S., Lu X.: Hybrid materials and polymer electrolytes for electrochromic device applications. Advanced Materials, 24, 40714096 (2012).

DOI: $10.1002 / \mathrm{adma} .201200213$
[11] Balan A., Baran D., Toppare L.: Benzotriazole containing conjugated polymers for multipurpose organic electronic applications. Polymer Chemistry, 2, 1029-1043 (2011). DOI: 10.1039/C1PY00007A

[12] Karsten B. P., Bijleveld J. C., Viani L., Cornil J., Gierschner J., Janssen R. A.: Electronic structure of small band gap oligomers based on cyclopentadithiophenes and acceptor units. Journal of Materials Chemistry, 19, 5343-5350 (2009). DOI: $10.1039 / \mathrm{B} 901374 \mathrm{~A}$

[13] Jiang J-M., Yang P-A., Hsieh T-H., Wei K-H.: Crystalline low-band gap polymers comprising thiophene and 2,1,3-benzooxadiazole units for bulk heterojunction solar cells. Macromolecules, 44, 9155-9163 (2011). DOI: $10.1021 / \mathrm{ma} 201848 \mathrm{z}$

[14] Pati P. B., Das S., Zade S. S.: Benzooxadiazaole-based D-A-D co-oligomers: Synthesis and electropolymerization. Journal of Polymer Science Part A: Polymer Chemistry, 50, 3996-4003 (2012).

DOI: $10.1002 /$ pola.26195

[15] Ding P., Zhong C., Zou Y., Pan C., Wu H., Cao Y.: 5,6bis(decyloxy)-2,1,3-benzooxadiazole-based polymers with different electron donors for bulk-heterojunction solar cells. Journal of Physical Chemistry C, 115, 16211-16219 (2011). DOI: $10.1021 / j p 2031434$

[16] Lee J-K., Gwinner M. C., Berger R., Newby C., Zentel R., Friend R. H., Sirringhaus H., Ober C. K.: High-performance electron-transporting polymers derived from a heteroaryl bis(trifluoroborate). Journal of the American Chemical Society, 133, 9949-9951 (2011). DOI: $10.1021 / \mathrm{ja} 201485 \mathrm{p}$

[17] Song S., Jin Y., Park S. H., Cho S., Kim I., Lee K., Heeger A. J., Suh H.: A low-bandgap alternating copolymer containing the dimethylbenzimidazole moiety. Journal of Materials Chemistry, 20, 6517-6523 (2010).

DOI: 10.1039/C0JM00772B

[18] Shim J. Y., Lee B. H., Song S., Kim H., Kim J. A., Kim I., Lee K., Suh H.: Synthesis and properties of the conjugated polymers with indenoindene and benzimidazole units for organic photovoltaics. Journal of Polymer Science Part A: Polymer Chemistry, 51, 241-249 (2013). DOI: $10.1002 /$ pola.26385

[19] Shin S. A., Park J. B., Kim J-H., Hwang D-H.: Synthesis and characterization of 2,1,3-benzoselenadiazolebased conjugated polymers for organic photovoltaic cells. Synthetic Metals, 172, 54-62 (2013).

DOI: 10.1016/j.synthmet.2013.04.004

[20] Gibson G. L., McCormick T. M., Seferos D. S.: Atomistic band gap engineering in donor-acceptor polymers. Journal of the American Chemical Society, 134, 539-547 (2012).

DOI: $10.1021 / \mathrm{ja} 208917 \mathrm{~m}$

[21] Welch G. C., Bazan G. C.: Lewis acid adducts of narrow band gap conjugated polymers. Journal of the American Chemical Society, 133, 4632-4644 (2011). DOI: $10.1021 / \mathrm{ja} 110968 \mathrm{~m}$ 
[22] Sun Y., Chien S-C., Yip H-L., Zhang Y., Chen K-S., Zeigler D. F., Chen F-C., Lin B., Jen A. K-Y.: Highmobility low-bandgap conjugated copolymers based on indacenodithiophene and thiadiazolo[3,4-c]pyridine units for thin film transistor and photovoltaic applications. Journal of Materials Chemistry, 21, 13247-13255 (2011).

DOI: $10.1039 / \mathrm{C} 1 \mathrm{JM} 11564 \mathrm{~B}$

[23] Wen W., Ying L., Hsu B. B. Y., Zhang Y., Nguyen T-Q., Bazan G. C.: Regioregular pyridyl[2,1,3]thiadiazoleco-indacenodithiophene conjugated polymers. Chemical Communications, 49, 7192-7194 (2013).

DOI: $10.1039 / \mathrm{C} 3 \mathrm{CC} 43229 \mathrm{G}$

[24] Price S. C., Stuart A. C., Yang L., Zhou H., You W.: Fluorine substituted conjugated polymer of medium band gap yields $7 \%$ efficiency in polymer-fullerene solar cells. Journal of the American Chemical Society, 133, 4625-4631 (2011).

DOI: $10.1021 /$ ja1112595

[25] Albrecht S., Janietz S., Schindler W., Frisch J., Kurpiers J., Kniepert J., Inal S., Pingel P., Fostiropoulos K., Koch N., Neher D.: Fluorinated copolymer PCPDTBT with enhanced open-circuit voltage and reduced recombination for highly efficient polymer solar cells. Journal of the American Chemical Society, 134, 14932-14944 (2012).

DOI: $10.1021 / \mathrm{ja3} 05039 \mathrm{j}$

[26] Dou L., Chen C-C., Yoshimura K., Ohya K., Chang WH., Gao J., Liu Y., Richard E., Yang Y.: Synthesis of $5 H$ dithieno[3,2-b:2',3'-d]pyran as electron-rich building block for donor-acceptor type low-bandgap polymers. Macromolecules, 46, 3384-3390 (2013).

DOI: $10.1021 / \mathrm{ma} 400452 \mathrm{j}$

[27] He Y., Wang X., Zhang J., Li Y.: Low bandgap polymers by copolymerization of thiophene with benzothiadiazole. Macromolecular Rapid Communications, 30, 45-51 (2009).

DOI: $10.1002 /$ marc. 200800507

[28] Nagarjuna G., Kokil A., Kumar J., Venkataraman D.: A straightforward route to electron transporting conjugated polymers. Journal of Materials Chemistry, 22, 16091-16094 (2012).

DOI: 10.1039/C2JM32217J

[29] Ku S-Y., Liman C. D., Burke D. J., Treat N. D., Cochran J. E., Amir E., Perez L. A., Chabinyc M. L., Hawker C. J.: A Facile synthesis of low-band-gap donor-acceptor

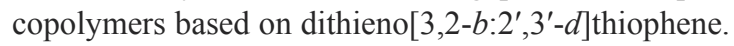
Macromolecules, 44, 9533-9538 (2011).

DOI: $10.1021 / \mathrm{ma} 202095 \mathrm{j}$

[30] Lee J., Cho S., Seo J. H., Anant P., Jacob J., Yang C.: Swapping field-effect transistor characteristics in polymeric diketopyrrolopyrrole semiconductors: Debut of an electron dominant transporting polymer. Journal of Materials Chemistry, 22, 1504-1510 (2012).

DOI: $10.1039 / \mathrm{C} 1 \mathrm{JM} 14549 \mathrm{E}$
[31] Li H., Tam T. L., Lam Y. M., Mhaisalkar S. G., Grimsdale A. C.: Synthesis of low band gap [1,2,5]-thiadiazolo[3,4-g]quinoxaline and pyrazino[2,3-g]quinoxaline derivatives by selective reduction of benzo[1,2-c; 4,5-c' $]$ bis $[1,2,5]$ thiadiazole. Organic Letters, 13, 4649 (2011).

DOI: $10.1021 / 01102465 \mathrm{a}$

[32] Zha D., Chen L., Wu F., Wang H., Chen Y.: Modulation of the molecular geometry of carbazolebis(thiadiazole)-based conjugated polymers for photovoltaic applications. Polymer Chemistry, 4, 2480-2488 (2013). DOI: 10.1039/C3PY21113D

[33] Dong Y., Hu X., Duan C., Liu P., Liu S., Lan L., Chen D., Ying L., Su S., Gong X., Huang F., Cao Y.: A series of new medium-bandgap conjugated polymers based on naphtho[1,2-c:5,6-c]bis(2-octyl-[1,2,3]triazole) for high-performance polymer solar cells. Advanced Materials, 25, 3683-3688 (2013).

DOI: $10.1002 / \mathrm{adma} .201301547$

[34] Wei P., Duan L., Zhang D., Qiao J., Wang L., Wang R., Dong G., Qiu Y.: A new type of light-emitting naphtho[2,3-c][1,2,5]thiadiazole derivatives: Synthesis, photophysical characterization and transporting properties. Journal of Materials Chemistry, 18, 806-818 (2008).

DOI: 10.1039/B714539J

[35] Park H. J., Lee Y., Jo J. W., Jo W. H.: Synthesis of a low bandgap polymer based on a thiadiazolo-indolo $[3,2-b]$ carbazole derivative for enhancement of open circuit voltage of polymer solar cells. Polymer Chemistry, 3, 2928-2932 (2012).

DOI: $10.1039 / \mathrm{C} 2 \mathrm{PY} 20417 \mathrm{G}$

[36] Yuen J. D., Fan J., Seifter J., Lim B., Hufschmid R., Heeger A. J., Wudl F.: High performance weak donoracceptor polymers in thin film transistors: Effect of the acceptor on electronic properties, ambipolar conductivity, mobility, and thermal stability. Journal of the American Chemical Society, 133, 20799-20807 (2011). DOI: $10.1021 / \mathrm{ja} 205566 \mathrm{w}$

[37] Patel D. G., Feng F., Ohnishi Y-Y., Abboud K. A., Hirata S., Schanze K. S., Reynolds J. R.: It takes more than an imine: The role of the central atom on the electron-accepting ability of benzotriazole and benzothiadiazole oligomers. Journal of the American Chemical Society, 134, 2599-2612 (2012). DOI: $10.1021 /$ ja207978v

[38] Arias A. C., MacKenzie J. D., McCulloch I., Rivnay J., Salleo A.: Materials and applications for large area electronics: Solution-based approaches. Chemical Reviews, 110, 3-24 (2010). DOI: $10.1021 / \mathrm{cr} 900150 \mathrm{~b}$

[39] Neo W. T., Loo L. M., Song J., Wang X., Cho C. M., Chan H. S. O., Zong Y., Xu J.: Solution-processable blue-to-transmissive electrochromic benzotriazole-containing conjugated polymers. Polymer Chemistry, 4, 4663-4675 (2013).

DOI: $10.1039 / \mathrm{C} 3 \mathrm{PY} 00677 \mathrm{H}$ 
[40] Lim S. Z. H., Neo W. T., Cho C. M., Wang X., Tan A. Y. X., Chan H. S. O., Xu J.: Electrochromic $\pi$-conjugated copolymers derived from azulene, fluorene, and dialkyloxybenzothiadiazole. Australian Journal of Chemistry, 66, 1048-1056 (2013).

DOI: $10.1071 / \mathrm{CH} 13147$

[41] Neo W. T., Cho C. M., Song J., Chin J. M., Wang X., He C., Chan H. S. O., Xu J.: Solution-processable multicolored dithienothiophene-based conjugated polymers for electrochromic applications. European Polymer Journal, 49, 2446-2456 (2013).

DOI: $10.1016 /$ j.eurpolymj.2013.02.026

[42] Ding G., Cho C. M., Chen C., Zhou D., Wang X., Tan A. Y. X., Xu J., Lu X.: Black-to-transmissive electrochromism of azulene-based donor-acceptor copolymers complemented by poly(4-styrene sulfonic acid)-doped poly(3,4-ethylenedioxythiophene). Organic Electronics, 14, 2748-2755 (2013).

DOI: $10.1016 /$ j.orgel.2013.07.037

[43] Chen M. S., Niskala J. R., Unruh D. A., Chu C. K., Lee O. P., Fréchet J. M. J.: Control of polymer-packing orientation in thin films through synthetic tailoring of backbone coplanarity. Chemistry of Materials, 25, 40884096 (2013).

DOI: $10.1021 / \mathrm{cm} 402489 \mathrm{a}$

[44] Frisch M. J., Trucks G. W., Schlegel H. B., Scuseria G. E., Robb M. A., Cheeseman J. R., Scalmani G., Barone V., Mennucci B., Petersson G. A., Nakatsuji H., Caricato M., Li X., Hratchian H. P., Izmaylov A. F., Bloino J., Zheng G., Sonnenberg J. L., Hada M., Ehara M., Toyota K., Fukuda R., Hasegawa J., Ishida M., Nakajima T., Honda Y., Kitao O., Nakai H., Vreven T., Montgomery J. A., Peralta J. E. Jr., Ogliaro F., Bearpark M., Heyd J. J., Brothers E., Kudin K. N., Staroverov V. N., Kobayashi R., Normand J., Raghavachari K., Rendell A., Burant J. C., Iyengar S. S., Tomasi J., Cossi M., Rega N., Millam M. J., Klene M., Knox J. E., Cross J. B., Bakken V., Adamo C., Jaramillo J., Gomperts R., Stratmann R. E., Yazyev O., Austin A. J., Cammi R., Pomelli C., Ochterski J. W., Martin R. L., Morokuma K., Zakrzewski V. G., Voth G. A., Salvador P., Dannenberg J. J., Dapprich S., Daniels A. D., Farkas Ö., Foresman J. B., Ortiz J. V., Cioslowski J., Fox D. J.: Gaussian 09, Revision A.2. Gaussian Inc., Wallingford, USA (2009).

[45] Carsten B., He F., Son H. J., Xu T., Yu L.: Stille polycondensation for synthesis of functional materials. Chemical Reviews, 111, 1493-1528 (2011).

DOI: $10.1021 / \mathrm{cr} 100320 \mathrm{w}$

[46] Balan A., Baran D., Gunbas G., Durmus A., Ozyurt F., Toppare L.: One polymer for all: Benzotriazole containing donor-acceptor type polymer as a multi-purpose material. Chemical Communications, 44, 67686770 (2009).

DOI: $10.1039 / \mathrm{B} 912482 \mathrm{~A}$

[47] Qiao X., Wang X., Mo Z.: The $\mathrm{FeCl}_{3}$-doped poly(3alkyithiophenes) in solid state. Synthetic Metals, 122, 449-454 (2001).

DOI: $10.1016 / \mathrm{S} 0379-6779(00) 00587-7$
[48] Helgesen M., Gevorgyan S. A., Krebs F. C., Janssen R. A. J.: Substituted 2,1,3-benzothiadiazole- and thiophene-based polymers for solar cells - Introducing a new thermocleavable precursor. Chemistry of Materials, 21, 4669-4675 (2009). DOI: $10.1021 / \mathrm{cm} 901937 \mathrm{~d}$

[49] Pasker F. M., Le Blanc S. M., Schnakenburg G., Höger S.: Thiophene-2-aryl-2H-benzotriazole-thiophene oligomers with adjustable electronic properties. Organic Letters, 13, 2338-2341 (2011).

DOI: $10.1021 / 012005853$

[50] Davey A. P., Elliot S., O’Connor O., Blau W.: New rigid backbone conjugated organic polymers with large fluorescence quantum yields. Journal of the Chemical Society, Chemical Communications, 14, 1433-1434 (1995). DOI: $10.1039 / \mathrm{C} 39950001433$

[51] Ding G., Zhou H., Xu J., Lu X.: Electrofluorochromic detection of cyanide anions using a benzothiadiazolecontaining conjugated copolymer. Chemical Communications, 50, 655-657 (2014).

DOI: $10.1039 / \mathrm{C} 3 \mathrm{CC} 47732 \mathrm{~K}$

[52] Zhang Y., Zou J., Yip H-L., Sun Y., Davies J. A., Chen K-S., Acton O., Jen A. K-Y.: Conjugated polymers based on $\mathrm{C}$, Si and N-bridged dithiophene and thienopyrroledione units: Synthesis, field-effect transistors and bulk heterojunction polymer solar cells. Journal of Materials Chemistry, 21, 3895-3902 (2011).

DOI: 10.1039/C0JM03927F

[53] Chang H-H., Tsai C-E., Lai Y-Y., Chiou D-Y., Hsu S-L., Hsu C-S., Cheng Y-J.: Synthesis, molecular and photovoltaic properties of donor-acceptor conjugated polymers incorporating a new heptacylic indacenodithieno [3,2-b]thiophene arene. Macromolecules, 45, 92829291 (2012).

DOI: $10.1021 / \mathrm{ma3} 019552$

[54] Azoulay J. D., Koretz Z. A., Wong B. M., Bazan G. C.: Bridgehead imine substituted cyclopentadithiophene derivatives: An effective strategy for band gap control in donor-acceptor polymers. Macromolecules, 46, 1337-1342 (2013).

DOI: $10.1021 / \mathrm{ma} 302569 \mathrm{u}$

[55] Shi Q., Fan H., Liu Y., Chen J., Ma L., Hu W., Shuai Z., Li Y., Zhan X.: Side chain engineering of copolymers based on bithiazole and benzodithiophene for enhanced photovoltaic performance. Macromolecules, 44, 4230-4240 (2011). DOI: $10.1021 / \mathrm{ma} 200576 \mathrm{y}$

[56] Yang S., Olishevski P., Kertesz M.: Bandgap calculations for conjugated polymers. Synthetic Metals, 141, 171-177 (2004). DOI: 10.1016/j.synthmet.2003.08.019

[57] Ma J., Li S., Jiang Y.: A time-dependent DFT study on band gaps and effective conjugation lengths of polyacetylene, polyphenylene, polypentafulvene, polycyclopentadiene, polypyrrole, polyfuran, polysilole, polyphosphole, and polythiophene. Macromolecules, 35, 1109-1115 (2002).

DOI: $\underline{10.1021 / \mathrm{ma} 011279 \mathrm{~m}}$ 
[58] Yigitsoy B., Karim S. M. A., Balan A., Baran D., Toppare L.: Multichromic polymers of benzotriazole derivatives: Effect of benzyl substitution. Electrochimica Acta, 56, 2263-2268 (2011).

DOI: $10.1016 /$ j.electacta.2010.11.052
[59] Haynes W. M.: CRC handbook of chemistry and physics. CRC Press, Boca Raton (2014).

[60] Sonmez G., Meng H., Wudl F.: Organic polymeric electrochromic devices: Polychromism with very high coloration efficiency. Chemistry of Materials, 16, 574580 (2004).

DOI: $10.1021 / \mathrm{cm} 0301773$ 